\title{
On some problems of communicative competency of preschool teachers
}

\author{
N.V. Savina ${ }^{*}$, N.P. Murzina ${ }^{2}$ and E.V. Namsing ${ }^{3}$ \\ ${ }^{1}$ Omsk state pedagogical University, Omsk, Russia \\ ${ }^{2}$ Omsk state pedagogical University, Omsk, Russia \\ ${ }^{3}$ Omsk state pedagogical University, Omsk, Russia
}

\begin{abstract}
The article substantiates the importance of communicative competency for a modern professional, the professional activity of a teacher and specifically a preschool teacher. The results of studying individual components of communicative competency among teachers of preschool educational organizations are presented. The deficiencies in its development are highlighted and the possibilities of the educational process in a higher educational institution and methodological support in a preschool educational organization in the development of this competency are shown.
\end{abstract}

\section{A problem statement}

The importance of communication for life in society is beyond doubt. However, when at the end of the $20^{\text {th }}$ century there was a "communication explosion", even more attention was paid to sociability, interpersonal communication, communicative competence, the ability to interact. Competence in the field of communication has become one of the main components of a high professional level of a specialist in any field of human activity. This was also facilitated by the development of new means of communication, the active use of the Internet as the main means of communication. According to the 2016 World Economic Forum report on the ten skills necessary for any person in the fourth industrial revolution, this skill is referred to as the "coordination with others" [1]. Communication is included in the set of " $4 \mathrm{~K}$ " - key competencies, the elements of which differ from other competences of the $21^{\text {st }}$ century in that they are implemented on any subject material and are a complex manifestation of the cognitive and personal characteristics observed in a person's behavior. In general, communication is the ability to quickly and productively establish contacts, listen to and hear the interlocutor, convey one's point of view to other people, be able to build collaborative relationships, enter into cooperation with others. In Russia, the training of specialists has begun in accordance with the new updated higher education standards (Federal State Educational Standards of Higher Education (FSES HE)), where there is a block of mandatory universal competences (UCs) [2]. These competencies correspond to the core skills of the $21^{\text {st }}$ century. As for pedagogical fields of study, such standards have been in effect since 2019. Also, starting from 2020, the certification of teachers in Russia

${ }^{*}$ Corresponding author: ipcs-profped@yandex.ru 
will be carried out on the basis of unified federal assessment materials (UFAM), one of the blocks of these tools includes the "Block for assessing teachers' psychological, pedagogical and communicative competences" [3]. Communication as a skill is extremely important for a teacher for two reasons. Firstly, the teaching profession is based on communication, interaction with different social groups. Secondly, one of the global tasks of a teacher is to prepare a student for life in society, form and develop his/her communication skills not only at the current level, as well as at the level predicted in the future. Also, the future of education is closely related to communication as a skill. The Atlas of New Professions, developed at Skolkovo, presents the professions that will emerge after 2020 in the field of education: a designer of states-of-consciousness training tools, a game teacher, a designer of educational trajectories, a mind fitness instructor. Among the supra-professional skills these specialists should have, there are several skills and abilities included in the communicative competency: interdisciplinary communication, customer-focusedness, working with people [4]. In this article, the authors did not set the task to strictly adhere to any approach to the relationship between the concepts of competence and competency, based on the research of M.S. Dobryakova, I.D. Frumin on this issue: "These differences in the use of terms for practical purposes are irrelevant. All of them denote the qualities each person needs that can be applied in different contexts. Therefore, in order to avoid confusion, the authors will adhere to the term "key competencies": it is consistently used in the main European policy documents" [5]. Hence, in the article, the authors talk about communicative competency (skill), although in the above-mentioned regulatory documents it is declared as a competence.

The problem of developing communicative competency among preschool teachers was addressed. Starting from the preschool level of education a child enters the world of other people. The result of socialization depends on a child's teacher in the kindergarten. Modern preschool education is an intrinsically valuable structure of education in the Russian Federation, the effectiveness of which largely depends on the level of development of a teacher's communicative competency, his/her ability to adequately perceive, accept, understand and support a child. A teacher does all this along with teaching a preschooler how to build constructive interaction with peers and adults in different situations of communication and interaction. In contrast to school, the communicative process in a preschool educational organization has its own special features owing to the specifics of the professional activities of specialists, the age and individual capabilities of communicants, the focus of activities on providing conditions for the full development of a child's individuality, the optimal fulfillment of his/her ability to self-development. When using variable styles of pedagogical communication, a teacher needs to take into account the fact that at this moment a child's "I-Image" is being formed, as well as his/her natural tendency to be better. At the same time, the ability of a preschool teacher to choose speech means, communication methods aimed at the efficient regulation of behavior and activities of preschoolers is of great importance. In addition, the professional position of a teacher is to create communication situations with children as full-fledged partners, which excludes any manipulations. When making direct and indirect contacts, the preferred communicative tactic is the cooperation with the use of a variety of communicative means that stimulate preschoolers' activity.

\subsection{The objective of the work}

Communication occupies an important place in the teaching profession; one can say that it largely determines the style of pedagogical activity, the choice of children's education and upbringing models. There is an issue of special features of teachers' communicative competency, taking into account their professional tasks and children's age peculiarities. To 
address this issue, it is necessary to consider the theoretical foundations of the formation of the phenomenon of "teacher's communicative competency", which were laid down in the studies of national and foreign researchers from the perspective of an activity approach. In the structure of professional-pedagogical activity, the researchers of this phenomenon (N.V. Kuzmina) recognized a communicative component, along with the constructive and organizational ones, which is characterized by a teacher's skills of pedagogical communication and interaction and includes the actions related to the establishment of pedagogically expedient relationships (with students, their parents, colleagues at work, administration) in the process of direct interaction with them in the course of solving a pedagogical task [6]. It is necessary to start the analysis of the scientific category "communicative competency" with a consideration of the approaches of national psychologists and teachers (A.A. Leontiev, I.A. Zimnyaya, V.A. Kan-Kalik, etc.) to the definition of the essence of teachers' communicative activity, pedagogical communication. These authors showed that this specific type of a teacher's activity is presented as a multidimensional system that includes structural components (perception, communication, interaction), functions (informational, projective, presentation, emotive ones, etc.), personal qualities (respect for the interlocutor, responsiveness, volitional qualities, etc.) and professional skills (listen, perceive, understand, evaluate, etc.), forms of communication (subject-object and subject-subject ones), the specificity of pedagogical communication is determined by pedagogical tasks in interaction and communication with children, parents, colleagues. The teacher's communicative competency from the perspective of the activity approach is presented as "a whole multi-storey structure: activity-interactioncommunication-contact". A.A. Leontiev defines pedagogical communication as "socially oriented communication", "group subject-oriented communication", "personality-oriented communication" [7]. Canadian scientists (M. Kanal and M. Swain) studied communicative competency in connection with the problems of learning a second language in Ontario schools, emphasized the role of practical language skills in communication, the linguistic plan in the formation of communication and recognized the following components: "grammatical competence; sociolinguistic competence; discursive competence; strategic competence" [8]. This proves that the following components are important for effective communication: the ability to think logically in the speech activity, knowledge, skills, social standards and relationships for using a language in communication and interaction, the ability to be aware of having difficulties in communication and build a strategy for their resolution. Analyzing the experience of foreign colleagues from Germany (D. Spanhel) on conducting a "microanalysis" of the teacher's language in the communication activity with students, A.A. Leontiev showed that the success of pedagogical in-class activities largely depends on language and speech utterances. It was found that at all stages, from motivation to the stage of receiving feedback from children, teachers give preference to the following speech techniques: explanation, justification, addition, example, requirement, instruction [7]. As can be seen, teachers give preference to the authoritarian style of communication when choosing speech techniques. This can be explained by the insufficient training of teachers in the field of studying the socio-psychological mechanisms of various types of speech activity. Therefore, research of pedagogical communication as a system of social and pedagogical interaction becomes relevant nowadays. V.A. Kan-Kalik described eight models of pedagogical communication through the characteristics of a teacher's interaction with children in communication: friendly attitude, enthusiasm, distance, intimidation, dalliance [9]. The author thought that the content of pedagogical communication is determined by the communicative task and communicative actions. Studying the problems of communication ontogeny, M.I. Lisina comes to the conclusion that communicative activity is synonymous with communication, and distinguishes components in communication in accordance with the structure of activity, supplementing them with "the 
subject of communication (a communication partner as a subject) and communication means (operations contributing to communication actions)", the choice of which depends on the communicative task [10]. These studies show the importance of the ability to define and formulate a communicative task for the teacher before the planned communication with children and the ability to correct it during direct communication. A.K. Markova, one of the first scholars to study teachers' competency at work, identified a special group of communicative competency skills associated with "methods of setting a wide range of communicative tasks". She also emphasized that the main thing in this skill is "the creation of conditions for psychological safety and the implementation of internal reserves of a communication partner" [11]. Thus, studies of pedagogical communication by national psychologists and teachers from the perspective of the activity approach have created the basis for determining the components of a teacher's communicative competency. From the perspective of the competency-based approach, a teacher's communicative competency is considered by national psychologists and teachers, coordinating their views with "discoverers" of the competency-based approach (J. Raven), through the system of "knowledge, skills, abilities, as well as methods and techniques of their implementation in the activity (self-development) of an individual" [12]. It seems necessary to consider the views of I.A. Zimnyaya in studying a specialist's key competencies: she highlighted competencies related to the interaction of a person with other people in different spheres of his/her life and competency in communication [13]. The author expanded the characteristics of competence as a structural unit of competency in a certain type of activity, in addition to knowledge, skills and methods of their implementation, and highlighted the following aspects: a motivational aspect (readiness), a value-semantic aspect (attitude) and emotional-volitional regulation of the process and result of competency manifestation. The manifestation of communicative competency is fully characterized by the subjective position of participants in communication, a teacher's recognition of students' partner position in this process [13]. This approach in defining the communicative competency of a teacher is fully consistent with a personality-oriented educational model.

When considering the activities of a preschool teacher in detail, the authors point out that a teacher's communicative skills are widely used not only in working with children, but also in building competent, expedient relationships with parents, colleagues, administration and the professional community at various levels of pedagogical communication. Clause 3.4.2 of the Federal State Educational Standard of Preschool Education states that "Pedagogical workers implementing the Program must have the basic competencies necessary to create the conditions for children development, indicated in Clause 3.2.5 of this Standard" [14]. In national pedagogy, a significant number of studies (V.I. Yashina, E.I. Tikheeva, E.A. Flerina and others) are devoted to the problems of speech training of preschool education specialists. These issues are considered in the aspect of organizing the speech environment in a preschool institution, improving speech culture and the level of development of speech etiquette of a preschool teacher. The concept of communicative competency, the history of emergence, development, methods of forming communicative competency are considered in the works by N.A. Vdovina, O.L. Vorobieva, E.N. Gusarova, V.I. Dolgova, E.V. Melnik, N. Karakhan, E.N. Komandin, E.V. Pozolotina and other authors. The formation of an effective communication style of a preschool teacher has been studied and presented in the studies by A.G. Ismagilova. The importance of communicative competency as a basic characteristic of a preschool teacher's professionalism is confirmed at the regulatory, scientific-theoretical and methodological levels (J. Bowden, 1998; I.N. Asaeva, 2008; M.M. Kovalevsky, O V. Gruzdeva, 2010; M. Yusoff, 2010; M.V. Tretyakova, A.A. Ignatenko, 2012; I.I. Barakhovich, 2015; A.R. Shangareeva, 2016; A.R. Ablitarova, O.A. Pshonnik, 2016). In addition, problems associated with an insufficient level of development of teachers' communicative competency are clearly indicated in many 
modern studies. For example, G.B. Monina singles out a number of reasons for typical mistakes made by teachers. Among them, there are teachers' ignorance of communication techniques; fussiness, hysterics, excessive emotionality in response to parents' words and actions; the use of stereotypes, attitudes that impede communication; aggression, assertiveness; indifference, sadness [15]. In her study, T.M. Babunova points out that only every fifth teacher adheres to a personality-oriented interaction model, a third of modern kindergarten teachers use an educational-disciplinary didactic approach, and the rest of them do not have a clear orientation towards a specific model [16]. The situation is also complicated by objective negative factors of the teacher's professional work (low wages, professional overload, high degree of responsibility, limitation of professional independence and initiative, etc.) [17], which directly affect the quality of the teacher's communication, primarily in terms of emotional behavior. All the specified problems indicate the existence of a contradiction between the requirements for the teacher's communicative competency, on the one hand, and insufficient attention to and awareness of this problem on the part of teachers and the management of preschool educational institutions, on the other hand.

\section{Materials and the results of the research}

The specified theoretical-methodological foundations of the competency-based and activity-based approaches in education made it possible to set the goal and objectives of the empirical part of the study. The main goal is to identify the level of development and significance of individual structural components of the communicative competence of teachers working in preschool educational organizations (PEOs). Research objectives are as follows: to study teachers' communicative competency by indicators laid down in regulatory documents (Professional Standard and FSES HE); to specify these indicators from the standpoint of the teacher's professional communication skills and conduct a similar study; to obtain an expert assessment of these indicators carried out by methodologists of preschool educational organizations; to conduct a comparative analysis of the self-assessment of teachers and experts. Agreeing with the opinion that communicative competency is not limited to a set of knowledge, but determines the need to possess it, to apply it in practice [18], the authors have selected the appropriate diagnostic tools. To determine the activity characteristics of teachers' communicative competency, a questionnaire was drawn up on some skills from the Draft Professional Standard for a Preschool Education Teacher and indicators of universal competence "Communication" of the FSES HE in the field of study "Pedagogical education", at the master's degree level. The indicators were taken from the basic educational program for "preschool education" profile, implemented at the Omsk State Pedagogical University. Knowledge indicators were included in the questionnaire, but in an insignificant amount. The examinees were asked to assess the importance of indicators for their professional activities and the degree of their manifestation on a 10-point scale; they were also assessed by an expert - a methodologist of the organization. To clarify the characteristics of communicative competency, professional communication skills were identified and the diagnostic method "Map of Communicative Competence of a Preschool Teacher" (A.A. Mayer, L.G. Bogoslavets) was selected [19]. This map has been revised and supplemented with due account for the needs of this study. The diagnostics assumed that communicative competency was determined on the basis of several types of assessments, two of which were given by a teacher and one of them - by an expert (a senior teacher of the PEO). The teachers were asked to assess 20 communication skills on a 10 -point scale: 0 point - the minimum significance, 10 points the maximum significance. In the first two columns, teachers were asked to assess the significance of each communicative skill and the degree of formation of a particular skill. 
The third column was intended for assessment by an expert, who was a senior teacher of the PEO.

The empirical study involved teachers of PEOs - kindergartens in Omsk, the Russian Federation, Nos. 2, 100, 311, 50 people in total. Kindergartens were selected on the basis of a disproportionate stratified selection. There are 184 municipal kindergartens in Omsk. All of them can be divided into several groups by type of organization. The authors randomly selected one kindergarten from the most numerous groups: a kindergarten, a kindergarten a child development center, a kindergarten - a child development center with combined groups.

The results of studying the assessment and self-assessment of indicators of communicative competency from the training and professional activity standards are presented below (Table 1).

Table 1. Summary results of significance, self-assessment and expert assessment ranks.

\begin{tabular}{|c|c|c|c|c|c|c|}
\hline No. & Competence indicators & $\begin{array}{l}\text { Significance } \\
\text { rank }\end{array}$ & $\begin{array}{l}\text { Self- } \\
\text { assessment } \\
\text { rank }\end{array}$ & $\begin{array}{l}\text { Expert } \\
\text { assessment } \\
\text { rank }\end{array}$ & $\begin{array}{l}\text { d } \\
(4-3)\end{array}$ & $\begin{array}{l}d \\
(5-4)\end{array}$ \\
\hline 1 & 2 & 3 & 4 & 5 & 6 & 7 \\
\hline 1 & $\begin{array}{l}\text { Knows how to } \\
\text { communicate } \\
\text { children, taking ith } \\
\text { account their age and } \\
\text { individual peculiarities }\end{array}$ & 5 & 4 & 5 & -1 & +1 \\
\hline 2 & $\begin{array}{l}\text { Knows how to establish } \\
\text { emotional contact with } \\
\text { children }\end{array}$ & 1 & 3 & 1 & +2 & -2 \\
\hline 3 & $\begin{array}{l}\text { Shows respect for } \\
\text { children's human dignity }\end{array}$ & 2 & 1 & 2 & -1 & +1 \\
\hline 4 & $\begin{array}{l}\text { Knows the rules of } \\
\text { professional ethics }\end{array}$ & 3 & 2 & 3 & -1 & +1 \\
\hline 5 & $\begin{array}{l}\text { Knows communication } \\
\text { methods for professional } \\
\text { interaction }\end{array}$ & 4 & 5 & 4 & +1 & -1 \\
\hline 6 & $\begin{array}{l}\text { Knows modern means of } \\
\text { information } \\
\text { communication } \\
\text { technologies }\end{array}$ & 6.5 & 8 & 6.5 & +1.5 & -1.5 \\
\hline 7 & $\begin{array}{l}\text { Knows how to draw up } \\
\text { written texts of official } \\
\text { style of speech on } \\
\text { professional issues in } \\
\text { Russian }\end{array}$ & 6.5 & 7 & 6.5 & +0.5 & -0.5 \\
\hline 8 & $\begin{array}{l}\text { Knows how to draw up } \\
\text { written texts of official } \\
\text { style of speech on } \\
\text { professional issues in a } \\
\text { foreign } \\
\text { (languages) language }\end{array}$ & 12 & 11 & 12 & -1 & +1 \\
\hline 9 & $\begin{array}{l}\text { Knows how to present the } \\
\text { results of professional } \\
\text { activities in Russian }\end{array}$ & 8 & 6 & 8 & -2 & +2 \\
\hline 10 & $\begin{array}{l}\text { Knows how to present the } \\
\text { results of professional } \\
\text { activity in a foreign } \\
\text { language (languages) }\end{array}$ & 13 & 13 & 13 & 0 & 0 \\
\hline
\end{tabular}




\begin{tabular}{|l|l|l|l|l|l|l|}
\hline No. & Competence indicators & $\begin{array}{l}\text { Significance } \\
\text { rank }\end{array}$ & $\begin{array}{l}\text { Self- } \\
\text { assessment } \\
\text { rank }\end{array}$ & $\begin{array}{l}\text { Expert } \\
\text { assessment } \\
\text { rank }\end{array}$ & $\begin{array}{l}\text { d } \\
\mathbf{( 4 - 3 )}\end{array}$ & $\begin{array}{l}\text { d } \\
\mathbf{( 5 - 4 )}\end{array}$ \\
\hline 11 & $\begin{array}{l}\text { Knows how to use modern } \\
\text { means of information and } \\
\text { communication for } \\
\text { technologies } \\
\text { professional interaction }\end{array}$ & 9 & 9 & 9 & 0 & 0 \\
\hline 12 & $\begin{array}{l}\text { Has the skills of applying } \\
\text { modern communication } \\
\text { technologies for } \\
\text { professional interaction }\end{array}$ & 10 & 10 & 10 & 0 & 0 \\
\hline 13 & $\begin{array}{l}\text { Has the skills of applying } \\
\text { modern communication } \\
\text { technologies in a foreign } \\
\text { language (languages) for } \\
\text { professional interaction }\end{array}$ & 11 & 12 & 11 & +1 & -1 \\
\hline
\end{tabular}

The highest ranks were given to specific skills for interacting with children and the ethical rules - sub-items 2, 3, 4. They all reflect the skills of the Draft Professional Standard. The last ranks were given to the skills and abilities of using a foreign language in professional activities - sub-items $8,10,13$, which was predictable. Then, the authors were interested in how self-assessments of significance and manifestation of the studied indicators of teachers' communicative competence differ, as well as how much the external expert assessment differs from the teachers' self-assessment. It is clear from the table that in column 6, positive values show a discrepancy between the teachers' self-esteem and the significance of the indicator - the significance is higher than the implementation in practice. It means that teachers consider themselves not entirely prepared for the important, in their opinion, aspects of communicative competency. Column 7 shows positive values in a similar way - experts rate the work of teachers lower than the teachers themselves. Special attention should be paid to some indicators. Thus, the indicator "Knows how to establish emotional contact with children" is of interest, since it is assessed as the most important in the teacher's work. However, its implementation is assessed lower, although the assessment of the teacher's actions by an expert is high. This shows teachers' low selfesteem. Similarly, the results are presented for the indicator "Knows the methods of communication for professional interaction" - it takes the fourth, rather high, place in the order of significance and its manifestation in activities is lower, but experts rate teachers higher. The item "Knows how to communicate with children, taking into account their age and individual peculiarities" is of particular concern. This is the basic communication skill of a teacher. However, the teachers ranked it only fifth in order of significance, but they rated their skills higher - at the fourth place. Besides, experts evaluate teachers lower. The average values of the indicators are also of interest (Table 2).

Table 2. Average values of significance, self-assessment, expert assessment indicators.

\begin{tabular}{|c|c|c|c|c|c|c|}
\hline \multirow[t]{3}{*}{ Parameters } & \multirow[b]{3}{*}{ (No. 2, n=12) } & \multirow{2}{*}{\multicolumn{2}{|c|}{$x$}} & \multirow{2}{*}{\multicolumn{2}{|c|}{$x$}} & \multirow[b]{3}{*}{,$\Sigma$} \\
\hline & & & & & & \\
\hline & & $\begin{array}{l}\text { (No. } \\
\mathrm{n}=20)\end{array}$ & 100 & $\begin{array}{l}\text { (No. } \\
\mathrm{n}=18)\end{array}$ & 311, & \\
\hline Significance & 9.27 & 7.65 & & 8.88 & & 8.6 \\
\hline Self-assessment & 6.24 & 5.63 & & 7.31 & & 6.4 \\
\hline Expert & 6.25 & 5.95 & & 7.5 & & 6.57 \\
\hline
\end{tabular}


For all organizations, separately and in total, teachers rated themselves the lowest, their competency as a whole is assessed higher by an expert, although this difference is insignificant, one can only talk about a trend. An interesting fact is that the lowest results are in the organization that is considered exemplary in the city in terms of education quality, differentiation of educational services, social partnership, etc. Probably, the fear of not meeting high expectations, constantly growing requirements for teachers' competency have led to such results. The highest rates of self-assessment and external assessment are in the organization where there have recently been major changes in the staff structure. This can be explained by the dynamics of a small group, when at the stage of creation there are high expectations from work results, as well as a desire of each participant to present himself well.

Average results were shown by an organization that works in a standard way, does not take on increased obligations and has a stable staff. It should also be noted that in all organizations, the average scores of teachers and experts do not differ much. This is probably due to the procedure for filling out the questionnaires: first, the teacher assessed himself, and then - the expert who has already seen the teacher's assessment.

The next is the second direction of the authors' diagnostics. The initial matrix for constructing the Communicative Competency Map made it possible to form a qualimetric standard, in accordance with which 4 main levels of formation of the studied attribute have been identified. 0-3 points - unacceptable level; 4-5 points - critical level; 5-8 points acceptable level; 9-10 points - the optimal level of attribute formation.

In accordance with the algorithm for the qualimetric standard formation [19], the levels of development of the communicative competency of preschool teachers were calculated, and their qualitative characteristics were compiled. The results of assessing the levels of teachers' communicative competency development are presented in Table 3.

Table 3. Levels of teachers' communicative competency development (according to the "Map of Communicative Competency of a Preschool Teacher" by A.A. Mayer).

\begin{tabular}{|l|l|l|l|l|}
\hline \multirow{2}{*}{ Assessment } & \multicolumn{4}{|l|}{ Levels of teachers' communicative competency development } \\
\cline { 2 - 5 } & $\begin{array}{l}\text { Unacceptable level } \\
\mathbf{( 0 - 6 0} \text { points) }\end{array}$ & $\begin{array}{l}\text { Critical level } \\
(\mathbf{6 1 - 1 0 0} \text { points) }\end{array}$ & $\begin{array}{l}\text { Acceptable level } \\
(\mathbf{1 0 1 - 1 6 0} \text { points) }\end{array}$ & $\begin{array}{l}\text { Optimal level } \\
(\mathbf{1 6 1 - 2 0 0} \\
\text { points) }\end{array}$ \\
\hline Teachers & $0 \%$ & $0 \%$ & $32 \%$ & $68 \%$ \\
\hline Experts & $0 \%$ & $0 \%$ & $28 \%$ & $72 \%$ \\
\hline Average value & $0 \%$ & $0 \%$ & $30 \%$ & $70 \%$ \\
\hline
\end{tabular}

Based on the data in the table, it can be seen that the unacceptable and critical levels of communicative competency development have not been identified; the acceptable level is $32 \%$ (16 people) and 28\% (14 people), respectively; the optimal level is $68 \%$ (34 people) and $72 \%$ (36 people), respectively. Summarizing all the maps, the authors made a summary table that reflects the average estimates and the coefficient of differences of their significance.

The diagnostic results showed the presence of an acceptable and optimal level of development of the communicative competency of preschool teachers. Attention is drawn to the clearly high assessment of all communicative pedagogical skills by the majority of the respondents. Besides, it is worth noting a number of problems that the diagnostic study revealed. Firstly, evaluating a fairly wide range of communication tasks, many teachers undoubtedly overestimated their own assessment. This conclusion was made on the basis of the study of personal data related to the teachers' education, qualifications and professional experience, as well as data from the expert assessment, which was always lower than the teachers' self-assessment in this case. This applies to both young specialists with less than 
three years of professional experience and those who do not have basic pedagogical education. The teachers' overestimation of their own skills can be explained by the fear of competent control on the part of the PEO administration, as well as teachers' desire to enhance their own status in such a way. The second problem is the insufficient differentiation of skills among teachers. This was evident among many respondents in virtually the same, "average" assessments of skills that are different in structure. For example, skills No. 2, 5, 7, 11, 14 and 16 (see Table 4).

Table 4. Assessment of communicative competency of preschool teachers.

\begin{tabular}{|c|c|c|c|c|c|c|}
\hline \multirow[b]{2}{*}{$\begin{array}{l}\text { Communication skills of } \\
\text { a preschool teacher }\end{array}$} & \multicolumn{2}{|l|}{ Average score } & \multirow[t]{2}{*}{ d1* } & \multicolumn{2}{|c|}{ Average score } & \multirow[t]{2}{*}{ d2* } \\
\hline & Significance & $\begin{array}{l}\text { Degree of } \\
\text { developm } \\
\text { ent }\end{array}$ & & $\begin{array}{l}\text { Degree of } \\
\text { developm } \\
\text { ent }\end{array}$ & $\begin{array}{l}\text { Expert } \\
\text { assessm } \\
\text { ent }\end{array}$ & \\
\hline $\begin{array}{l}\text { 1) competently behave } \\
\text { during and after class } \\
\text { (posture, } \\
\text { expressions, movements, } \\
\text { pantomime) }\end{array}$ & 9.8 & 8.6 & -1.2 & 8.6 & 8.1 & -0.5 \\
\hline $\begin{array}{l}\text { 2) present yourself, } \\
\text { emphasize your dignity }\end{array}$ & 10 & 8.2 & -1.8 & 8.2 & 8.1 & -0.1 \\
\hline $\begin{array}{l}\text { 3) control and adjust your } \\
\text { emotional state and } \\
\text { behavior in general }\end{array}$ & 10 & 8.5 & -1.5 & 8.5 & 8.3 & -0.2 \\
\hline $\begin{array}{l}\text { 4) establish and maintain } \\
\text { emotional contact with } \\
\text { children }\end{array}$ & 10 & 8.8 & -1.2 & 8.8 & 8.3 & -0.5 \\
\hline $\begin{array}{l}\text { 5) relieve excessive } \\
\text { mental stress in yourself } \\
\text { and in preschoolers }\end{array}$ & 10 & 8.3 & -1.7 & 8.3 & 7.6 & -0.7 \\
\hline $\begin{array}{l}\text { 6) create an atmosphere of } \\
\text { safety, creativity and } \\
\text { inspiration in the } \\
\text { classroom }\end{array}$ & 10 & 9.1 & -0.9 & 9.1 & 8.5 & -0.6 \\
\hline $\begin{array}{l}\text { 7) arouse sympathy and } \\
\text { interest }\end{array}$ & 9.6 & 8.3 & -1.3 & 8.3 & 7.6 & -0.7 \\
\hline $\begin{array}{l}\text { 8) master the technology } \\
\text { of interaction and the } \\
\text { technique of speech } \\
\text { exposure (breathing, } \\
\text { diction, pace, voice) }\end{array}$ & 9.8 & 8.7 & -1.1 & 8.7 & 8.7 & 0 \\
\hline $\begin{array}{l}\text { 9) ask questions to } \\
\text { children and answer their } \\
\text { questions }\end{array}$ & 10 & 9.6 & -0.4 & 9.6 & 8,8 & -0.8 \\
\hline $\begin{array}{l}\text { 10) organize and maintain } \\
\text { contact during the lesson } \\
\text { (with a group, subgroup, } \\
\text { child) }\end{array}$ & 9.3 & 8.5 & -0.8 & 8.5 & 8.1 & -0.4 \\
\hline $\begin{array}{l}\text { 11) maintain constant } \\
\text { contact with the group, } \\
\text { feel the change in the } \\
\text { situation and react to it }\end{array}$ & 10 & 8.3 & -1.7 & 8.3 & 8.1 & -0.2 \\
\hline $\begin{array}{l}\text { 12) enter into, lead, } \\
\text { continue and stop the } \\
\text { interaction with a child, } \\
\text { subgroup, group }\end{array}$ & 9.6 & 8.4 & -1.2 & 8.4 & 8.2 & -0.2 \\
\hline
\end{tabular}




\begin{tabular}{|c|c|c|c|c|c|c|}
\hline \multirow[b]{2}{*}{$\begin{array}{l}\text { Communication skills of } \\
\text { a preschool teacher }\end{array}$} & \multicolumn{2}{|c|}{ Average score } & \multirow{2}{*}{ d1* } & \multicolumn{2}{|c|}{ Average score } & \multirow[t]{2}{*}{ d2* } \\
\hline & Significance & $\begin{array}{l}\text { Degree of } \\
\text { developm } \\
\text { ent }\end{array}$ & & $\begin{array}{l}\text { Degree of } \\
\text { developm } \\
\text { ent }\end{array}$ & $\begin{array}{l}\text { Expert } \\
\text { assessm } \\
\text { ent }\end{array}$ & \\
\hline $\begin{array}{l}\text { 13) reveal the potential of } \\
\text { a preschooler through the } \\
\text { organization of } \\
\text { communicative } \\
\text { interaction }\end{array}$ & 9.8 & 9.6 & -0.2 & 9.6 & 8.5 & -1.1 \\
\hline $\begin{array}{l}\text { 14) understand each child, } \\
\text { establish personal contact } \\
\text { with him/her }\end{array}$ & 10 & 8.1 & -1.9 & 8.1 & 7.7 & -0.4 \\
\hline $\begin{array}{l}\text { 15) have a special manner } \\
\text { of meeting with children, } \\
\text { reflecting the joy of } \\
\text { communication }\end{array}$ & 10 & 8.8 & -1.2 & 8.8 & 8.6 & -0.2 \\
\hline $\begin{array}{l}\text { 16) improvise, act and } \\
\text { speak impromptu }\end{array}$ & 10 & 8.3 & -1.7 & 8.3 & 8.1 & -0.2 \\
\hline $\begin{array}{l}\text { 17) have empathy } \\
\text { (understand, accept, } \\
\text { empathize, sympathize) }\end{array}$ & 10 & 9.0 & -1 & 9.0 & 8.7 & -0.3 \\
\hline $\begin{array}{l}\text { 18) rebuild relationships } \\
\text { with children, parents, } \\
\text { colleagues, administration }\end{array}$ & 10 & 8.7 & -1.3 & 8.7 & 7.3 & -1.4 \\
\hline $\begin{array}{l}\text { 19) inspire confidence, } \\
\text { remove resistance to } \\
\text { pedagogical influence, } \\
\text { tension }\end{array}$ & 10 & 9.1 & -0.9 & 9.1 & 8.4 & -0.7 \\
\hline $\begin{array}{l}\text { 20) choose a position and } \\
\text { role in communication } \\
\text { depending on the } \\
\text { circumstances }\end{array}$ & 10 & 8.4 & -1.6 & 8.4 & 8.0 & -0.4 \\
\hline Mean value & 9.8 & 8.6 & $\begin{array}{l}\mathrm{d} 1= \\
-1.2\end{array}$ & 8.6 & 8.1 & $\begin{array}{l}\mathrm{d} 2= \\
-0.4\end{array}$ \\
\hline
\end{tabular}

This circumstance may indicate both the formalism of a teacher and the lack of orientation in this issue, the lack of reflexive self-assessment skills. The analysis of the gaps (significance - degree of development) and (degree of development - expert assessment) presented in the table showed the problem areas in the practical activities of preschool teachers, associated with the need to relieve excessive mental stress in themselves and in preschoolers, arouse sympathy and interest, ask questions to children and answer their questions, understand each child, establish personal contact with him/her, rebuild relationships with children, parents, colleagues, administration. It is important to emphasize that senior teachers are more aware of these difficulties teachers have.

\section{Conclusions}

The importance of communicative competency of a modern specialist is confirmed by the development of society and technologies, when flexible, universal skills are valued. Communication has always been and remains the basis of the teachers' professional activity. It is especially important for a teacher working in preschool education to have a high level of communicative competency. In general, communicative competency is interpreted as the ability to establish contacts with different categories of people; it is also important for a teacher to recognize the partner position of students in this process. 
The results of empirical research showed the following. As for the indicators in the regulatory documents for teachers, the indicators of the Professional Standard turned out to be more significant than the ones of the university training standard - competencies associated with communication in a foreign language, as well as with the use of information technologies in some ways. There is virtually no need to present one's activity from the position of communication as a universal competence, including information and communication skills, and furthermore communication in a foreign language. On the one hand, this raises questions about the target guidelines for training students at the university. The authors have already analyzed the training of future teachers at the university from the standpoint of modern trends and concluded that it is necessary to both adjust training standards and the requirements for their implementation [20]. On the other hand, preschool education lags somewhat behind in terms of network activity, especially international interaction, but this does not mean that one does not need to be ready for this. Active interaction of preschool organizations, including at the international level, is a matter of time. An expert higher assessment of such universal skills of teachers allows concluding that if this need arises, teachers will be ready for such actions to some extent. Another important conclusion on these "regulatory" indicators is the tendency among teachers to underestimate the self-assessment in comparison with the external assessment of an expert. Unjustified dissatisfaction with oneself is the risk of a decrease in the quality of a teacher's psychosocial health and, as a consequence, a decrease in the quality of the activity. It was revealed that the results differ depending on the PEO type. Diagnostics of indicators of communicative competency for specific professional communication skills showed that the level of their development is generally at an acceptable and optimal level. However, on the contrary, an overestimation of self-assessment and a decrease in the external assessment of an expert can be observed. Hence, it can be stated that specific professional communication skills are better understood and meaningful for teachers than the category "Competence" in the universal sense. The requirements for these skills on the part of the management of PEOs are higher. Another problematic point was the lack of reflexive self-assessment skills among teachers, which is a matter of concern of the organization management in terms of methodological support.

In view of the foregoing, the following areas of professional training of future teachers and support of working preschool education teachers can be offered. At the stage of university training, future teachers need to be focused on the active development of preschool education in accordance with new social and technological challenges. In this regard, pedagogical foresight technologies, the integration of digital technologies and foreign language teaching technologies with specialized disciplines will be relevant. The teaching staff of PEOs needs to implement forms of methodological work, the content of which includes active-gaming methods, workshops and trainings, professional competitions, writing creative works, keeping an analytical diary, a discussion club, mutual visits of colleagues' lessons, aimed at teachers' understanding of the prospects of their own professional development, determination of one's own communicative characteristics and difficulties, finding an individual style of communication with all subjects of the educational process, using one's own talents, eliminating the weaknesses of communication activities, eliminating weaknesses and enhancing strengths through the perception of professional standards, mentoring and independent creative search.

\section{References}

1. The information resource «World Economic Forum. The 10 skills you need to thrive in the Fourth Industrial Revolution, available at», Switzerland, access mode: 
https://www.weforum.org/agenda/2016/01/the-10-skills-you-need-to-thrive-in-thefourth-industrial-revolution/

2. The information resource "Federal state educational standard (3++) for bachelor's and master's degrees. Portal of Federal state higher education standards», Russia, access mode: http://gosvo.ru/fgosvo/152/150/25/115

3. The information resource "Unified Federal assessment materials. (EFOM)», Russia, access mode: http://xn--e1aofx.xn--p1ai/

4. The information resource "Atlas of new professions», Russia, access mode: http://atlas100.ru/

5. M.S. Dobryakova, I.D. Frumin, Universal competences and new literacy: from slogans to reality, p. 474 (Ed. by M.S. Dobryakova, I.D. Frumin, Moscow.: High School of Economics, 2019)

6. N.V. Kuzmina, Professionalism of the activity of the teacher and the master of industrial training of the vocational school, p. 166 (Moscow: Higher School, 1989)

7. A.A. Leontyev, Pedagogical communication, p. 33 (Moscow: MGPI Publishing House, 1979

8. M. Canale, M. Swain, Theoretical Bases of Communicative Approaches to Second Language Teaching and Testing Applied Linguistics.Vol.1. Canada, access mode: https://www.researchgate.net/publication/31260438. (1980)

9. V.A. Kan-Kalik, To the teacher about pedagogical communication, p.190 (Moscow: Education, 1987)

10. M.I. Lisina, Problems of ontogenesis of communication. Moscow, access mode: https://www.klex.ru/kpo (1986)

11. A.K. Markova, Psychology of teacher's work, p.192 (Moscow: Education, 1993)

12. L.M. Mitina, Psychology of professional development, p.200 (Moscow: Flint: Moscow Psychological and Social Institute, 1998)

13. I.A. Zimnyaya, Key competencies are a new paradigm of educational outcomes, Higher education today, 5, 34-42. (2003)

14. The information resource «Federal State Educational Standard for Preschool Education», Russia, access mode: https://pravobraz.ru/federalnyj-gosudarstvennyjobrazovatelnyj-standart-doshkolnogo-obrazovaniya/

15. G.B. Monina, Communication training (teachers, psychologists, parents): psychological training, p. 224 (SPb: Publishing house "Rech", 2007)

16. G.A. Kuznetsova, V.V. Kolesnikova, T.M. Babunova, Socio-pedagogical interaction of participants in the educational process of preschool educational institutions as a condition for fostering a culture of behavior. Collection Diagnostics of social and pedagogical interaction of subjects of the educational process of preschool educational institutions, p. 12-19 (Moscow: Flint's, 2015)

17. E.G. Ozhogova, E.V. Namsing, Negative objective factors of a decrease in the productivity of professional and pedagogical activity, Konf., Childhood Open to the World, 289-293 (Omsk: Publishing house of OmGPU, February 25, 2019)

18. A.A. Isakova, Integration of Education, 21, 1, 46-53, (2017)

19. A.A. Mayer, L.D. Bogoslavets, Accompanying the professional success of a preschool teacher, 53-68 (TC Sphere, 2012) 
20. N.V. Savina, Training of teachers in the aspect of modern educational trends, Konf., Psychology of Education: Tradition and Innovation, p. 167-171 (Shadrinsk: Shadrinsk State Pedagogical University, November 20, 2018) 